DOI: https://doi.org/10.32839/2304-5809/2021-6-94-13

УДК 34.340

Золотухіна Л.О., Носенко Ю.В.

Дніпропетровський державний університет внутрішніх справ

\title{
ПЕРСОНАЛЬНІ ДАНІ ПРАЦІВНИКА: ПОНЯТТЯ ТА ПРАВОВЕ РЕГУЛЮВАННЯ
}

\begin{abstract}
Анотація. У статті проведено аналіз розвитку законодавства з проблем основних прав, свобод людини і громадянина, а також визначено, що основним інститутом, який забезпечуе захист прав, свобод людини і громадянина, в тому числі і в інформаційній сфрері, е держава, яке в результаті законодавчої діяльності має врегулювати поведінка суб'єктів відносин, пов'язаних із персональними даними. На основі узагальнення міжнародного досвіду з питань захисту персональних даних здійснено обгрунтування впливу європейських стандартів, досвіду демократичних країн і їх досягнень на організаційно-правовий механізм захисту персональних даних в Україні. Обгрунтовано розвиток організаційно-правових механізмів забезпечення захисту персональних даних, до яких слід віднести: ліцензування діяльності, реєстрацію баз і розпорядників персональних даних, сертифікацію інформаційних систем, в яких зберігаються і обробляються персональні дані.
\end{abstract}

Ключові слова: персональні дані, трудовий договір, особиста інформа-ція, відомості про особу, працівник, принципи захисту приватних даних.

Zolotukhina Lilia, Nosenko Yuliya

Dnipropetrovsk State University of Internal Affairs

\section{EMPLOYEE'S PERSONAL DATA: CONCEPT AND LEGAL REGULATION}

Summary. The article examines the concept of "personal data of the employee", as well as the development of its legal regulation in international and domestic legislation of the employee and the definition of the legal regulation of personal information protection in the process of employment. The article analyzes the development of legislation on the problems of fundamental rights, freedoms of man and citizen, and also determines that the main the institution that provides protection of human and civil rights, freedoms, including in the information sphere, is the state, which as a result of legislative activity should regulate the behavior of the subjects of relations related to personal data. On the basis of generalization of the international experience on personal data protection the substantiation of influence of the European standards, experience of the democratic countries and their achievements on organizational and legal is carried out. Personal data protection mechanism in Ukraine. The development of organizational and legal mechanisms to ensure the protection of personal data, which should include: licensing, registration of databases and managers of personal data, certification of information systems in which personal data is stored and processed. The paper classifies personal data according to the criterion of protection mechanism and access to personal data during their processing and circulation in state information resources Ukraine, reveals the concept of groups and categories of personal data, the essence of restricting access to personal data. It is proved that the system of personal data protection should include determining the procedure for access to personal data; determining the procedure for keeping records of transactions related to the processing of personal data; development of an action plan in case of unauthorized access to personal data, damage to technical equipment, emergencies; regular training of employees working with personal data. The directions of improvement of the state mechanisms of maintenance of protection of personal data in Ukraine by creation of the clear mechanism of realization of the human rights which are registered in the Constitution of Ukraine are offered; improving the rules for processing and disseminating personal data by their recipients and the process of controlling access to and dissemination of personal data, taking into account the provisions of Council of Europe and EU standards in the field of personal data protection. It is also proposed to establish an independent supervisory body in the field of access to information and protection of personal data: "National Committee for the Protection of Individuals' Rights Related to the Processing of Personal Data", which will help build an effective personal data protection system in Ukraine. both in the legal and in the institutional sense, as well as its main tasks and functions are defined. Taking into account the experience of European democracies, scientific and practical recommendations to the authorities on the mechanism of organizational and legal support for personal data protection have been developed.

Keywords: personal data, employment contract, personal information, personal information, employee, principles of private data protection.

$\Pi^{2}$ остановка проблеми. Протягом свого життя кожен надає інорормацію про себе іншим членам громади, державним установам, органам місцевого самоврядування, громадським організаціям. Надання особистої інформації людини також залежить від прийняття його н роботу. Відповідно до Кодексу законів про працю України громадянин зобов’язаний надати документи, що підтверджують його особу, що визначає рівень його знань та освіти, документи про медичний стан у передбачених законодавством України випадках та інші документи необхідні для вступу у трудові відносини.
Як результат, роботодавець має певну інформацію про працівника, яка включається до його особистої справи та зберігається не лише під час його перебування на посаді, але й під час звільнення. Персональні дані працівників містять особисту або сімейну таємницю громадян, їхнє приватне життя і включаються до різної індрормації, захищеної від несанкціонованого доступу.

Інформащія часто зберігається в електронному вигляді і може бути доступною для будь-кого i може призвести до переслідування законних прав та інтересів працівників. 
Аналіз останніх досліджень i публікацій. Поняття персональних даних досліджені у працях В.С. Венедіктова, М.М. Грекової, В.В. Жернакова, М.I. Іншина, М.М. Клемпарського, Є.В. Краснова, К.Ю. Мельника, С.М. Прилипка, Р.І. Чанишева, Г.І. Чанишевої, А.М. Чернобай, O.M. Ярошенка.

Мета статті. Головною метою цієї роботи є дослідження поняття «персональні дані працівника», а також розвиток його правового регулювання в міжнародному та вітчизняному законодавстві працівника та визначення особливостей правового регулювання захисту персональної інформації у процесі здійснення трудової діяльності.

Виклад основного матеріалу дослідження. Визначення персональних даних вперше з'являеться в Європейській раді з захисту персональної інформації з посиланням на Директиву про персональні дані від 28 січня $1981 \mathrm{p}$. № 108 [6], де термін «особиста інформація» стосується індормації про конкретну особу, або таку особа, яку можна ідентифікувати.

«Персональні дані» будь-яка інформація, що стосуеться встановлення фрізичної чи фрізичної особи, яку можна встановити (суб'єкт даних); особу, яку можна встановити, е така, яка може бути встановленою прямо чи опосередко-вано, зокрема за допомогою ідентифікаційного або одного чи більше фокторів, притаманних фрізичним, фізіологічним, розумовим, економічним, культурним чи соціальним аспектам їі особистості. Конституція України запроваджуе положення міжнародних актів, що забороняють втручання у приватне та сімейне життя, за винятком випадків, передбачених Конституцією України.

Відповідно до ст. 32 Конституції України, «ніхто не може піддаватися свавільному втручанню в його приватне життя, сім'ю, будинок або листування, а також вчиняти замах на його честь і репутацію. Збір, зберігання, використання та розповсюдження конфіденційної інформації про особу без дозволу не дозволяеться, крім випадків, визначених законом, лише в інтересах національної безпеки, економічного добробуту та прав людини».

Основний закон також гарантуе право вільно збирати, зберігати, використовувати та поширювати інформацію, крім випадків, передбачених законом. Наприклад, на практиці ці права повинні бути обмежені для захисту прав та інтересів закону, щоб запобігти розголошенню конфіденційної інформації [4].

Надання особистої інформації людини часто залежить від іï роботи. Після укладання трудового договору громадянин повинен надати паспорт або інший документ, що посвідчуе особу, трудову книжку та у випадках, передбачених законодавством, також документи про освіту (спеціалізацію, кваліфікацію), стан здоров'я та інші документи. На практиці більшість цього переліку документів, включаючи персональні дані працівників, була значно розширена. Наприклад, для збільшення заробітної плати на банківському рахунку працівника останній надає дані цього банківського рахунку або повідомляе роботодавця про наявність посвідчення водія на оплату службового транспортного засобу. Персональні дані працівників відображають особисту або сімейну таємницю громадян, їх приватне життя і е частиною інформації, захищеної від несанкціонованого доступу [3].

Відповідно до статті 11 Закону «Про інформацію» від 02.10.1992 р., персональні дані - це відомості чи сукупність відомостей про фізичну особу, яка ідентифікована або може бути ідентифікована [8].

Відповідно до глави 1 розділу 1 ст. 11 Закону «Захист персональних даних» від 01.01.2011р. Причинами права на використання персональних даних е згода суб’екта персональних даних, пов'язана з обробкою його персональних даних [7]. Тобто, з одного боку, законодавещь надає особі право дати згоду на використання ії персональних даних, з іншого боку, передбачає адміністративну, цивільну та кримінальну відповідальність власника персональних даних за їх використання без дозволу.

Відповідно до ст. 280 Цивільного кодексу України, якщо особисто спричинене порушенням його особистих немайнових прав в результаті майнової та (або) моральної шкоди, така шкода підлягае відшкодуванню [10].

Інформація про особисті дані особи зберігається в ії особистій справі в електронному вигляді або у формі файлів. Використовуючи автоматизовані системи та комп'ютерні технології, така інформація може бути доступною для будь-кого і може призвести до придушення законних прав та приватних інтересів, а також можливості незаконного втручання у приватне життя інших людей. Зловживання такою інформацією може призвести до матеріальних або поведінкових проблем. У трудовому праві не існуе технічного механізму захисту персональних даних працівників так, як ст. 32 Конституції України не фрігуруе в трудовому законодавстві України. Відповідно до чинного Закону про працю України немае жодного розділу про правовий захист персональної інформації працівників, який був би особливо важливим для розвитку інформації та технологій в комп'ютерах та мережах зв'язку.

Також важливим для розуміння поняття та змісту персональних даних е рішення Конституційного Суду України у справі про конституційне подання Жашківської районної ради Черкаської області про офіційне тлумачення поло-жень розділу 1, 2 ст. 32, розділ 2, ст. 34 Конституції України від 20 січня 2012 р. № 2-рп / 2012 [9]. Згідно з рішенням Конститущійного Суду України, під інформаціею про особисте та сімейне життя особи (особиста інформація про неї) слід розуміти будь-яку інформацію або тип інформації про ідентифіковану особу або інформацію, що ідентифікуе приватно, наприклад: освіта, сімейний стан, релігійні вірування, медичний статус, матеріальний стан, адреса, дата та місце народження, місце проживання тощо, інформація про особисте майно та немайнові відносини ціеї особи з іншими особами, включаючи членів сім'ї, а також інформація про події та явища, що відбулися або відбуваються внутрішньо, інтимно, в бізнесі та інших аспектах життя людини, крім виконання дієздатності особи, яка обіймае посаду, пов'язаної з виконанням діяльності держави або місцевого самоврядування. Така інформація про особу та її сім'ю $є$ конфріденційною і може розголошуватися лише за іх згодою, за винятком випадків, передбачених законодавством, і може використовуватися лише для цілей національної 
безпеки, економічного добробуту та прав людини. Виходячи з вищевикладеного, Конституційний Суд України дійшов висновку, що перелік персональних даних, який визначається як конфіденційна інфрормація.

Конфріденційна інфрормація про особу включає, але не обмежується ними, інформацію про іiі народження, освіту, сімейний стан, релігійні вірування, медичний стан, а також адресу, дату та місце народження, інфрормацію про їі майновий стан та іншу особисту інорормацію. Ту саму позицію висловило українське Міністерство юстиції, підтвердивши дійсний запит на український закон «Захист персональних даних» від 21 грудня 2011 р. [2], зазначивши, що українське законодавство не може встановити чіткий перелік інфрормації про фрізичну особу, які $є$ персональними даними, можливість застосування положень Закону в різних контекстах, включаючи обробку персональних даних та фрайлів персональних даних, які можуть виникнути в майбутньому внаслідок саморозкриття, зміни в технічних, соціальних, економічних та інших аспектах соціального життя. Перелік персональних даних $\epsilon$ надзвичайно динамічним і залежить насамперед від конкретної сфери правовідносин, що виникають у конкретної особи (власника чи власника персональних даних) та інших [11].

Бувають ситуації, коли людина вступає в ділові відносини і відмовляеться давати згоду на використання своєї особистої інформації.

Укласти трудовий договір без отримання, зберігання та використання інформації неможливо. Закон також забороняє відмову в працевлашту- ванні, оскільки особа не дає згоди на обробку своїх персональних даних. Відповідь на питання про те, як діяти в даній ситуації роботодавцям до сьогоднішнього дня закон не визначає [4].

Однак, у ст. 25 КЗПП України забороняеться орендодавцю вимагати документи при прийомі на роботу, що не передбачено законом. Також заборонено вимагати інформацію про партійну приналежність, нащіональність та походження. Ця стаття, власне, дозволяе працівникові відмовляти роботодавцю в інформації, що не пов'язана 3 якістю навичок та знань, необхідних для роботи. Відповідно до п. 2 ч. 2 ст. 15 Закону України «Про захист персональних даних» від 01.01.2011 р., персональні дані, що знаходяться в базі даних, зазнають знищення в разі припинення юридичних контактів, якщо інше не передбачено законом [7]. Якщо ми говоримо про трудові правовідносини, то їх припинення ототожнюеться з припинення трудового договору між працівником і роботодавцем. Але відповідно до Наказу Мін'юсту від 12.04.2012 № 578/5 документи особової справи зберігаються 75 років після звільнення працівника [5].

Висновки. Отже, будь-яка інформація, що стосується конкретного працівника та необхідна роботодавцеві виключно для її використання у процесі трудової діяльності, е персональними даними працівника. Для вдосконалення системи захисту персональних даних необхідно чітко закріпити у законодавстві випадки, у яких не потрібна згода працівника на обробку особистої інформації, та вдосконалити механізми захисту персональних даних працівників.

\section{Список літератури:}

1. Про захист фізичних осіб у зв'язку з автоматичною обробкою персональних даних і про вільне переміщення таких даних : Директива 95/46/ЄС Європейського парламенту і Ради від 24 жовтня 1995 р. URL: http://zakon2.rada.gov.ua/laws/show/994_242

2. Деякі питання практичного застосування Закону України «Про захист персональних даних» : роз'яснення Міністерства юстиції України від 21 грудня 2011 р.

3. Клачкова Т.В. Персональные данные работников: необходимость правового регулирования. Тенденции развития законодательства и совершенствование правоприленительной практики в совреленных условиях : Матер. Междунар. науч. конф. студ. и аспир., Минск, 19-20 окт. 2007 г. / отв. ред. Г.А. Шумак. Минск : БГУ, 2008. C. 176-177.

4. Кодекс законів про працю України від 10.12 .1971 р. Відолості Верховної Ради України.

5. Наказ Міністерства Юстиції України від 12.04.2012. Законодавство Украӥни. Документ № 578/5, чинний.

6. Про захист осіб у зв'язку з автоматичною обробкою персональних даних : Конвенція Ради Європи від 28 січня 1981 р. № 108. Офбіиійний вісник України. 2011. № 1. С. 701.

7. Про захист персональних даних: Закон України від 01.06.2010 № 2297-VI. Вiдомості Верховної Ради Украӥни. 2010. № 34. Ст. 481.

8. Про інформацію : Закон України від 02.10.1992 р. Відолості Верховної Ради Украйни. Документ № 2657-XII. 1992. № 48. Ст. 650.

9. Рішення Конституційного Суду України у справі за конституційним поданням Жашківської районної ради Черкаської області щодо офіційного тлумачення положень ч. 1, 2 ст. 32, ч. 2 , 3 ст. 34 Конституції України від 20 січня 2012 р. № 2-рп/2012. Офбіиійний вісник України. 2012. № 9. Ст. 332.

10. Цивільний кодекс України : Кодекс України від 16.01.2003. Документ 435-IV. Відолості Верховної Ради України. 2003. № 40-44. Ст. 356.

11. Чуприна О. Співвідношення понять «персональні дані, «інформація про особу», «конфіденційна інформація про особу». Підприєлство, господарство і право : наук-практ. госп-прав. журн. 2013. № 1. С. $104-108$.

\section{References:}

1. Pro zakhyst fizychnykh osib u zviazku $\mathrm{z}$ avtomatychnoiu obrobkoiu personalnykh danykh i pro vilne peremishchennia takykh danykh: Dyrektyva 95/46/IeS Yevropeiskoho parlamentu i Rady vid 24 zhovtnia 1995 r. URL: http://zakon2.rada.gov.ua/laws/show/994_242

2. Deiaki pytannia praktychnoho zastosuvannia Zakonu Ukrainy «Pro zakhyst personalnykh danykh»: roziasnennia Ministerstva yustytsii Ukrainy vid 21 hrudnia $2011 \mathrm{r}$.

3. Klachkova T.V. (2008) Personalnye dannye rabotnykov: neobkhodymost pravovoho rehulyrovanyia. Tendentsyy razuytyia zakonodatelstva y sover-shenstvovanye pravoprymenytelnoi praktyky $v$ sovremennykh uslovyiakh: Mater. Mezhdunar. nauch. konf. stud. y aspyr., Mynsk, 19-20 okt. 2007 h. / otv. red. H.A. Shumak. Mynsk: BHU, pp. $176-177$. 
4. Kodeks zakoniv pro pratsiu Ukrainy vid 10.12.1971 r. Vidomosti Verkhounoi Rady Ukrainy.

5. Nakaz Ministerstva Yustytsii Ukrainy vid 12.04.2012. Zakonodavstvo Ukrainy. Dokument № 578/5, chynnyi.

6. Pro zakhyst osib u zviazku z avtomatychnoiu obrobkoiu personalnykh danykh: Konventsiia Rady Yevropy vid 28 sichnia 1981 r. № 108. Ofitsiinyi visnyk Ukrainy. 2011. № 1. P. 701.

7. Pro zakhyst personalnykh danykh: Zakon Ukrainy vid 01.06.2010 № 2297-VI. Vidomosti Verkhounoi Rady Ukrainy. 2010. № 34. St. 481.

8. Pro informatsiiu: Zakon Ukrainy vid 02.10.1992 r. Vidomosti Verkhounoi Rady Ukrainy. Dokument № 2657-XII. 1992. № 48. St. 650.

9. Rishennia Konstytutsiinoho Sudu Ukrainy u spravi za konstytutsiinym podanniam Zhashkivskoi raionnoi rady Cherkaskoi oblasti shchodo ofitsiinoho tlumachennia polozhen ch. 1, 2 st. 32, ch. 2, 3 st. 34 Konstytutsii Ukrainy vid 20 sichnia 2012 r. № 2-rp/2012. Ofitsiinyi visnyk Ukrainy. 2012. № 9. St. 332.

10. Tsyvilnyi kodeks Ukrainy: Kodeks Ukrainy vid 16.01.2003. Dokument 435-IV. Vidomosti Verkhounoi Rady Ukrainy. 2003. № 40-44. St. 356.

11. Chupryna O. (2013) Spivvidnoshennia poniat "personalni dani, «informatsiia pro osobu», «konfidentsiina informatsiia pro osobu». Pidpryiemstvo, hospodarstvo i pravo: nauk-prakt. hosp-prav. zhurn, no. 1, pp. $104-108$. 